\title{
Early Holocene water budget of the Nakuru-EImenteita basin, Central Kenya Rift
}

\author{
Miriam Dühnforth · Andreas G. N. Bergner • \\ Martin H. Trauth
}

Received: 11 July 2005 / Accepted: 5 March 2006/Published online: 25 August 2006

(C) Springer Science+Business Media B.V. 2006

\begin{abstract}
The Nakuru-Elmenteita basin in the Central Kenya Rift, contains two shallow, alkaline lakes, Lake Nakuru (1770 m above sea level) and Lake Elmenteita (1786 m). Ancient shorelines and lake sediments at $\sim 1940$ m suggest that these two lakes formed a single large and deep lake as a result of a wetter climate during the early Holocene. Here, we used a hydrological model to compare the precipitation-evaporation balance during the early Holocene to today. Assuming that the Nakuru-Elmenteita basin was hydrologically closed, as it is today, the most likely climate scenario includes a $45 \%$ increase in mean-annual precipitation, a $0.5^{\circ} \mathrm{C}$ decrease in air temperature, and an increase of $9 \%$ in cloud coverage from the modern values. Compared to the modeling results from other East African lake basins, this dramatic increase in precipitation seems to be unrealistic. Therefore, we propose a significant flow of water from the early Holocene Lake Naivasha in the south towards the NakuruElmenteita basin to compensate the extremely
\end{abstract}

M. Dühnforth $(\bowtie)$

Institute of Geology, ETH Zürich, 8092 Zürich,

Switzerland

e-mail: duehnforth@erdw.ethz.ch

A. G. N. Bergner · M. H. Trauth

Institut für Geowissenschaften, Universität Potsdam,

Potsdam, Germany negative hydrological budget of this basin. Since we did not find any field evidence for a surface connection, as often proposed during the last 70 years, the hydrological deficit of the NakuruElmenteita basin could have also been compensated by a subsurface water exchange.

Keywords East Africa $\cdot$ Hydrological modeling $\cdot$ Paleoclimate $\cdot$ Nakuru-Elmenteita

\section{Introduction}

In East Africa, most climate records document dramatic hydrological changes since the Last Glacial Maximum (LGM) (e.g. Street-Perrott and Perrott 1993; Gasse 2000; Barker et al. 2003; Trauth et al. 2003). Orbitally-induced changes in the strength of the monsoon system and the intertropical convergence account for most of these long-term changes in tropical Africa. During the LGM (23-18 kyr BP), most records indicate a relatively dry climate, followed by a series of arid-humid transitions at 17-16, 15-14.5 and 12-11 cal. kyr BP (Barker et al. 2003). In contrast to these fluctuating conditions reflecting complex linkages between orbital forcing and oceanatmospheric interactions, the early Holocene climate was generally very wet in East Africa and surrounding areas (Gasse and van Campo 1994; Gasse 2000; Thompson et al. 2002). The wetter 
climate at $10-6 \mathrm{kyr}$ BP is generally attributed to a lower-latitude maximum in solar radiation at around $10.4 \mathrm{kyr} \mathrm{BP}$, an increase of the land-ocean pressure gradient, stronger lateral moisture transport and higher precipitation (Kutzbach and Street-Perrott 1985).

Paleoshorelines and associated sediments also document high lake levels in the Central Kenya Rift during the early Holocene (Washbourn 1967a; Washbourn-Kamau 1970; 1971; Richardson and Richardson 1972; Richardson and Dussinger 1986). Sediment characteristics and diatom assemblages contained in sediment cores provide further evidence for deep freshwater lakes at that time (Richardson and Dussinger 1986). Whereas there is no doubt about large lakes in the Nakuru-Elmenteita and Naivasha basins, the existence of an even larger Lake Nakuru-Elmenteita-Naivasha between 15 and 5 kyr BP has been intensely discussed for more than 70 years (e.g. Nilsson 1931; Butzer et al. 1972). Nilsson (1931) suggested that both lake basins were connected and contained one large Gamblian Lake (named after the Gamble's Cave south of modern Lake Nakuru), but paleoshorelines at the same elevation as in the Naivasha basin (2000 $\mathrm{m}$ above sea level, compared to the modern lake level at $1890 \mathrm{~m}$ ) have never been mapped in the Nakuru-Elmenteita basin (highest shorelines at $\sim 1940 \mathrm{~m})$. Hence, Butzer et al. (1972) published a map showing the outline of two separate early Holocene lakes with $\sim 60 \mathrm{~m}$ different lake levels in the Central Kenya Rift.

The hydrological connection of the two basins has important consequences for lake-balance modeling. Lake-balance models have become a widely accepted tool to link lake-level fluctuations with changes in the precipitationevaporation ratio in the catchment (Kutzbach 1980; Hastenrath and Kutzbach 1983; Bookhagen et al. 2001; Bergner et al. 2003). Ancient shorelines, beach gravels and the spatial distribution of lake sediments help to reconstruct the dimensions of paleolakes, which are then simulated using a hydrological model. Early low-resolution hydrological models applied to the lakes in the Central Kenya Rift during the early Holocene suggest an increase of $15-35 \%$ in precipitation as compared to today (Hastenrath and Kutzbach 1983). Recent high-resolution modeling for the Naivasha basin support these results $(16-32 \%$ more rain during the early Holocene, Bergner et al. 2003). Employing the same high-resolution model used by Bergner et al. (2003), we have now estimated the hydrological conditions in the Nakuru-Elmenteita basin and compared these with the hydrology of the Naivasha basin. The comparison of the two hydrological budgets allows us to assess a potential water exchange between the two high lakes and will provide a better estimate for the precipitation-evaporation balance during the early Holocene.

\section{Regional setting}

The Nakuru-Elmenteita basin is located in the Central Kenya Rift between $0^{\circ} \mathrm{S} 36^{\prime} \mathrm{E}$ and $1^{\circ} \mathrm{S}$ $36.5^{\prime} \mathrm{E}$ (Figs. 1 and 2). The deepest part of the basins contains two lakes, Lake Nakuru (1770 m above sea level) and Lake Elmenteita (1786 m). The catchment area of the Nakuru-Elmenteita basin is about $2390 \mathrm{~km}^{2}$ and the elevation ranges from 1760 to $3080 \mathrm{~m}$. On the western side, the basin is bounded by east-dipping normal faults of the Mau Escarpment $(3080 \mathrm{~m})$. To the east, the basin is bordered by west-dipping faults that separate the intra-rift Bahati-Kinangop Plateau $(2740 \mathrm{~m})$ from the eastern rift shoulder and the Aberdare Ranges $(3999 \mathrm{~m})$. The northern boundary comprises the Menengai Caldera $(2278 \mathrm{~m})$. To the south, the Mt. Eburru volcano $(2820 \mathrm{~m})$ separates the Nakuru-Elmenteita basin from the Naivasha Basin, which contains the modern Lake Naivasha (1890 m).

Regional climate is strongly influenced by the seasonal migration of the Intertropical Convergence Zone (ITCZ) and the coinciding precipitation pattern (Nicholson 1996; 2000). Rainfall associated with the transition of the ITCZ follows the highest sun in March and September with a lag of three to four weeks (Nicholson 2000). Therefore, the basin receives most of its precipitation during the "long rains" in April to May and the "short rains" in November. A third subordinate precipitation maximum occurs in September, when the Congo air masses transport moisture from the Congo basin to East Africa (Vincent 
Fig. 1 Topographic map of the East African Riftsystem and the location of the Central Kenya Rift (modified from Strecker 1991)

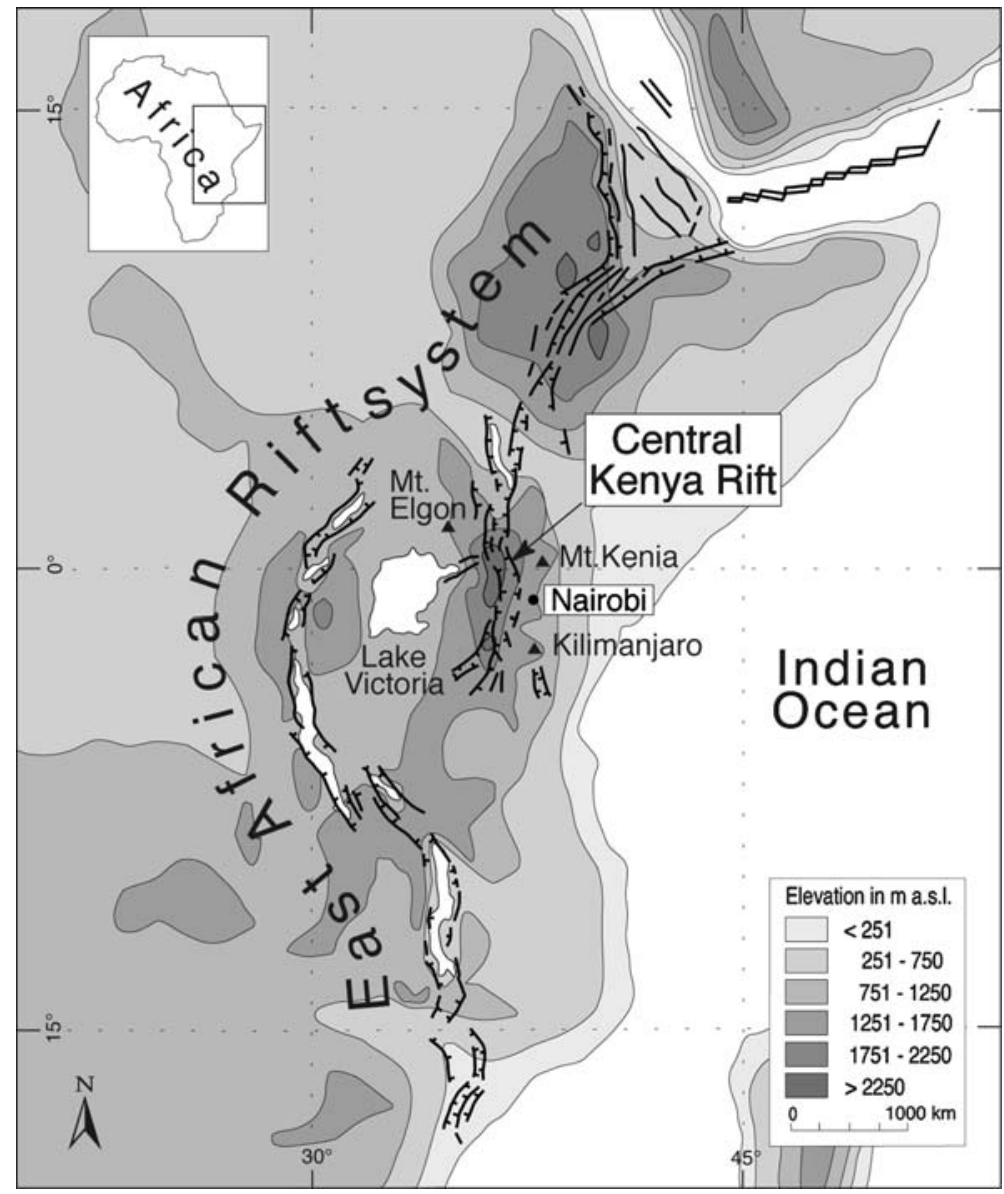

et al. 1979). Mean annual rainfall is $920 \mathrm{~mm} / \mathrm{y}$, whereas evaporation is about $1736 \mathrm{~mm} / \mathrm{y}$ (Kenya Meteorological Department 2000). The amount of precipitation is strongly linked to topography. Thus, the highest rates are obtained in the highelevation parts of the basin in the west and east, whereas the lower areas are relatively dry.

The long term hydrologic budget of the basin is primarily controlled by the spatial and temporal distribution of rainfall, superimposed on tectonically-driven influences on the drainage network and basin geometry (Strecker et al. 1990). Generally, north-south trending fault blocks deflect most of the rivers draining the Aberdare Ranges and Kinangop Plateau towards the south into the Naivasha basin (Fig. 2). Only minor rivers periodically drain into the Nakuru-Elmenteita basin. The freshwater character of modern Lake Naivasha is primarily attributed to this exceptional drainage pattern and strongly depends on the precipitation at high altitudes of the Aberdare Ranges (Richardson and Richardson 1972). In contrast, the lakes Nakuru and Elmenteita are highly alkaline with values between 120 and $1440 \mathrm{meq} / \mathrm{l}$ for Lake Nakuru (Beadle 1932; Talling and Talling 1965) and $290 \mathrm{meq} / \mathrm{l}$ for Lake Elmenteita (Talling and Talling 1965). The modern lakes Nakuru and Elmenteita cover an area of 26 and $40 \mathrm{~km}^{2}$, respectively. Both are shallow with an average water depth of less than $3 \mathrm{~m}$, fluctuating between 3 and $5 \mathrm{~m}$ since water levels have been recorded (Talling and Talling 1965).

\section{Methods}

The hydrologic modeling involved the (1) reconstruction of the 3D basin geometry and (2) the modeling of the modern and early Holocene hydrological budgets. To reconstruct the early 
Fig. 2 Topographic map of the Nakuru-Elmenteita and the adjacent Naivasha basin showing Lakes Nakuru, Elmenteita and Naivasha and their catchments

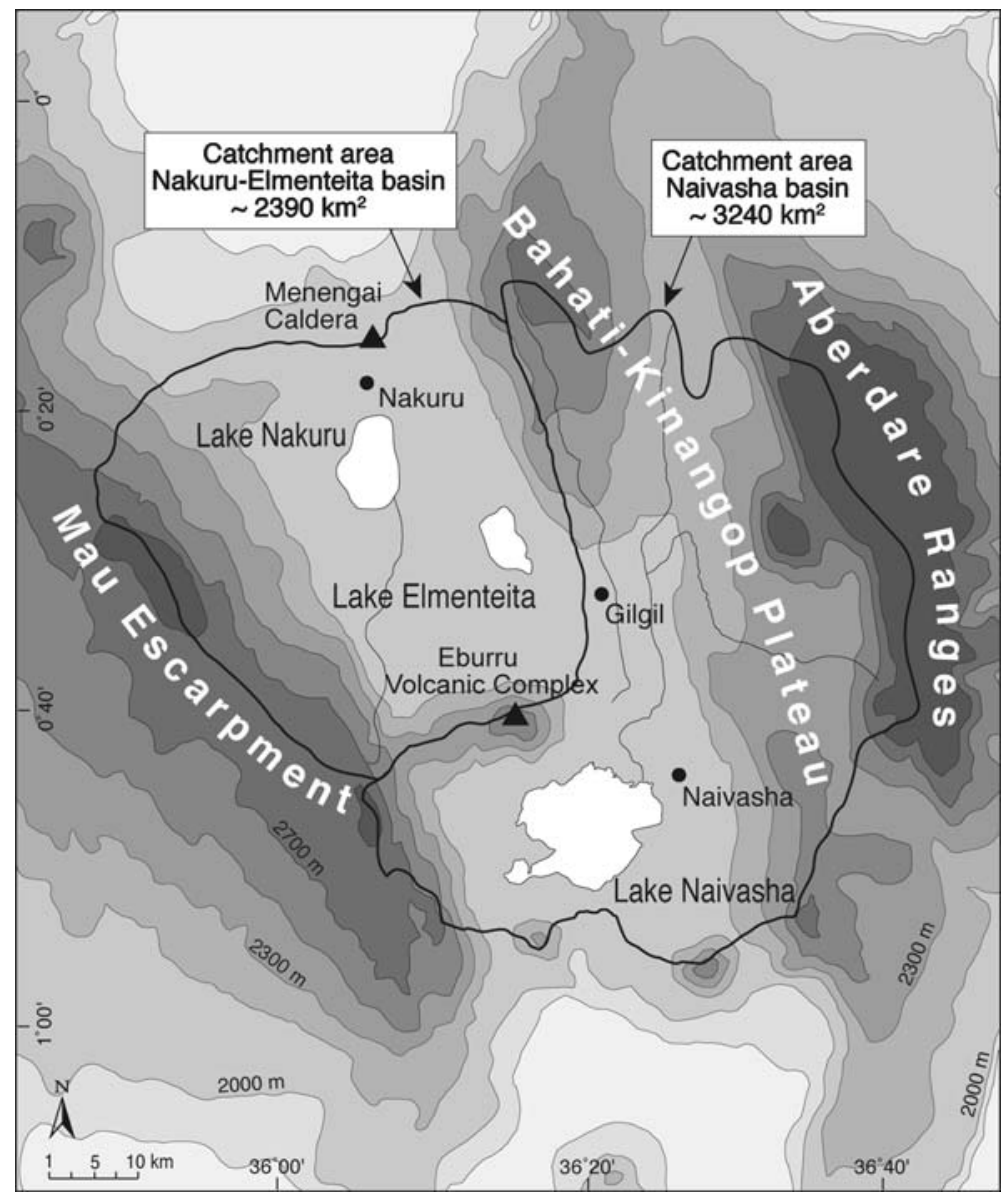

Holocene lake-level highstand, we mapped lake sediments and paleoshorelines in the Nakuru-Elmenteita basin. The ages of the lake deposits were determined by ${ }^{14} \mathrm{C}$ dating of snail shells sampled from diatomaceous silts at Lemulug crater, Karterit volcano and in a section east of Lake Elmenteita (Figs. 3 and 4). Our dataset is expanded by the descriptions of ${ }^{14} \mathrm{C}$-dated lake sediments and shorelines by Washbourn (1967a), WashbournKamau (1970), Washbourn-Kamau (1971) and Butzer et al. (1972). The preparation, pretreatment and measurement of the sample material was carried out at the Leibniz laboratory for radiometric dating and isotope research in Kiel. The calibration $(2 \sigma$ range) was done with CALIB 5.0.1 software (Stuiver and Reimer 1993). The altitude of the early Holocene shorelines was determined by Garmin eTrex Summit GPS and Thommen altimeter measurements. Replicate measurements were corrected for daily barometric trends. We compared our results with measurements by Washbourn (1967a) who used a Zeiss self-aligning level, the Survey of Kenya trigonometrical stations and benchmarks. Changes in the basin geometry in the course of volcano-tectonic processes are in the same order of magnitude as the accuracy of the GPS and altimeter measurements (Blisniuk 1988; Strecker et al. 1990; Strecker and Bosworth 1991).

Due to the extremely shallow water levels, the exact geometry of the modern water bodies is difficult to determine. The less than $3 \mathrm{~m}$ deep lakes are subject to dramatic fluctuations in water levels and completely disappear in dry years. However, a long-term average for the volumes of the water bodies could be inferred from the average water depth, lake area and bathymetry given by Washbourn (1967a). The early Holocene 
Fig. 3 Topographic map of the Nakuru-Elmenteita basin showing the outline of the modern and early Holocene Lakes Nakuru and Elmenteita and the location of the paleoshorelines and the lake-sediment outcrops.

$\mathrm{K} 1$ = Katerit,

$\mathrm{K} 2$ = Lemulug,

$\mathrm{K} 3$ = East Elmenteita,

K4 = Southwest

Elmenteita

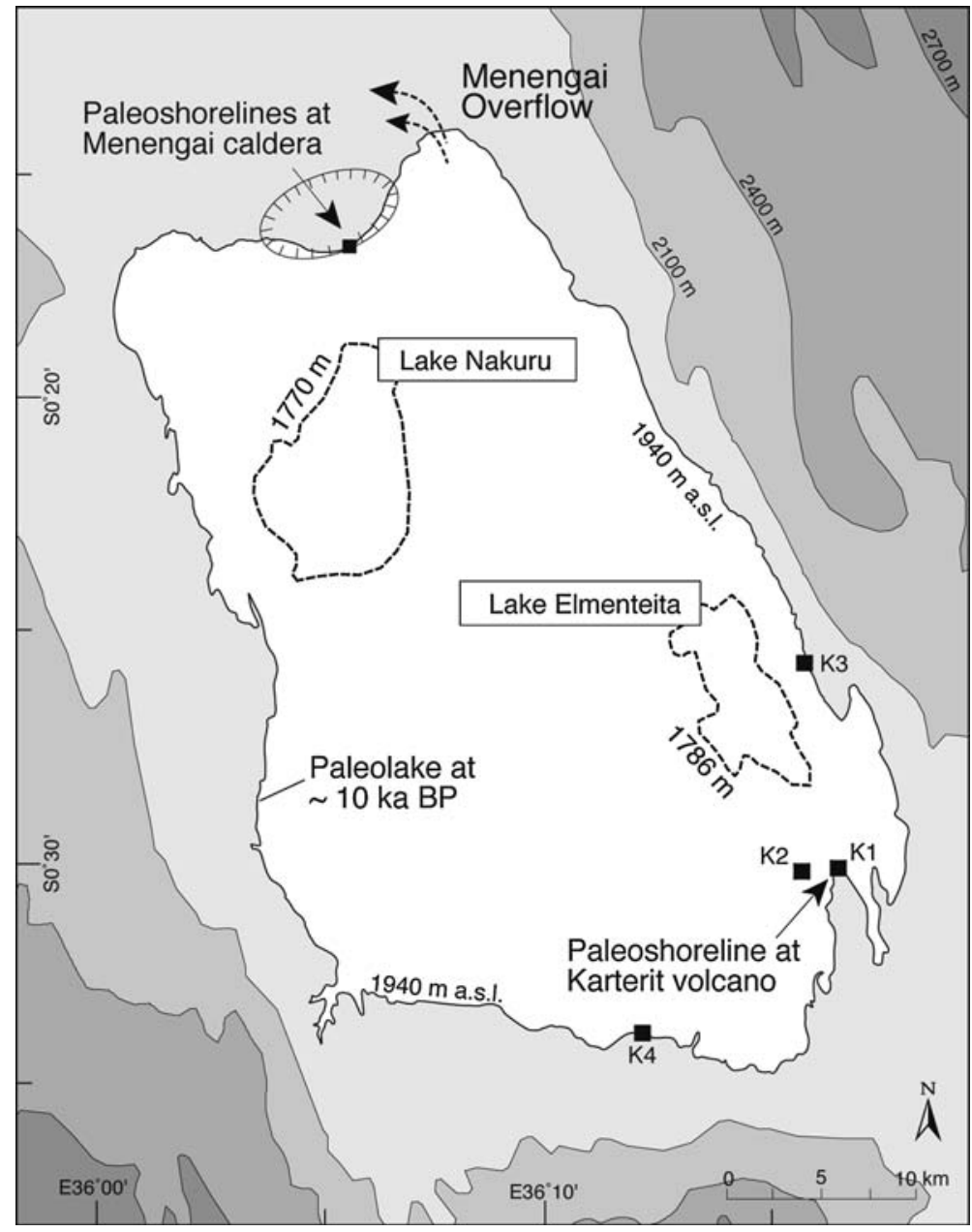

basin by Bergner et al. (2003). The model has been described in detail by these authors. It is based on the steady-state hydrological budget for a closed-basin lake that can be written as:

$$
\Delta V_{\text {lake }}=P_{\text {bas }}-\left[E_{\mathrm{w}} \alpha_{\mathrm{w}}+E_{\mathrm{l}}\left(1-\alpha_{\mathrm{w}}\right)\right]-S_{\text {bas }}=0
$$

$20 \mathrm{~m} \times 20 \mathrm{~m}$ grid using a Delaunay triangulation. Finally, we calculated the size of the catchment and the geometry of the water bodies, i.e. water depth, area and volume.

The lake-balance model used in this study calibrates an equilibrium lake level for closedbasin lakes using the mean basin-averaged precipitation and evaporation rate. The algorithm for this model was first introduced by Blodgett et al. (1997), then modified for modeling a landslidedammed lake in the Central Andes by Bookhagen et al. (2001) and recently applied to the Naivasha where $\Delta V_{\text {lake }}$ is the volumetric change in the water body, $P_{\text {bas }}$ the basin-averaged precipitation, $E_{\mathrm{w}}$ and $E_{\mathrm{l}}$ are the basin-averaged evaporation over water and over land, $\alpha_{\mathrm{w}}$ is the lake-area ratio and $S_{\text {bas }}$ is used to describe the basin-averaged seepage, which in our model is regarded to be zero (closed basin run). Before modeling the early Holocene highstand of Lake NakuruElmenteita, the model was tested for the modern conditions. The modern climatic parameters were 
a)

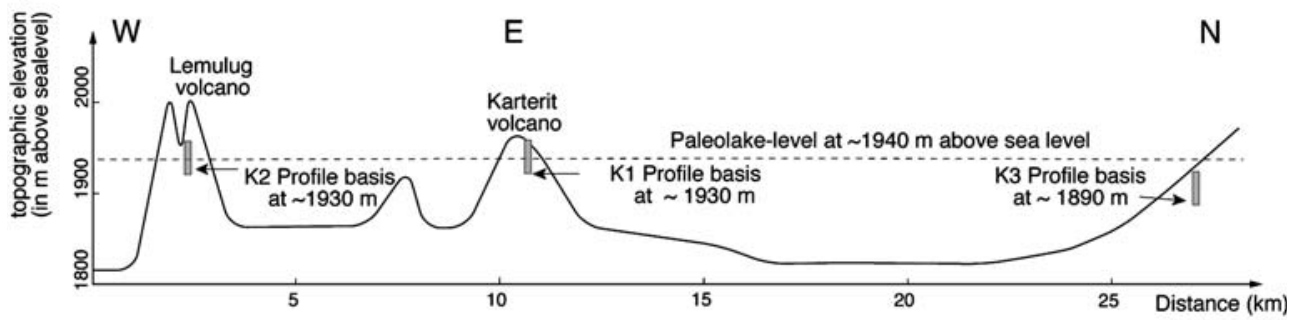

b)

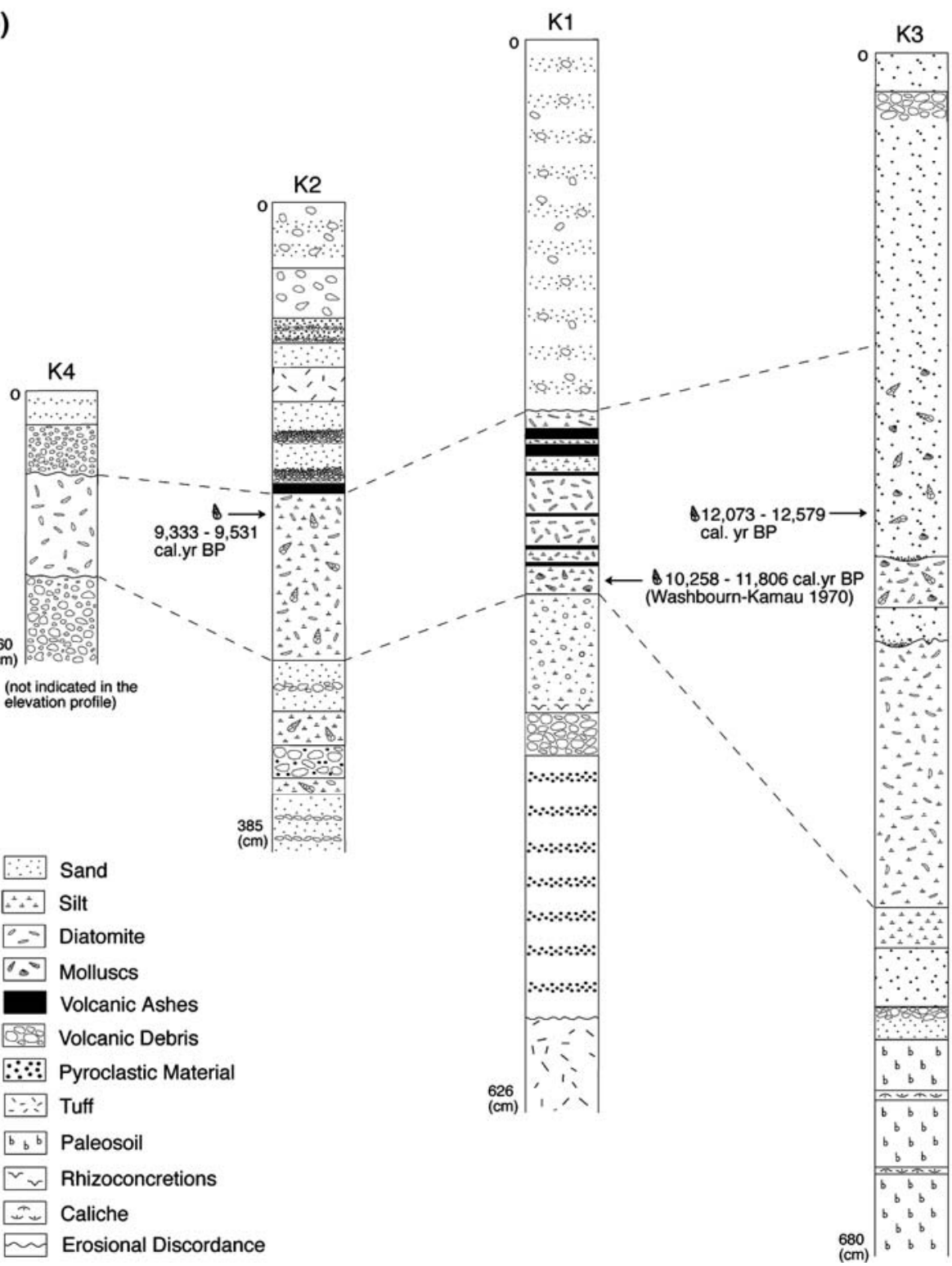

Fig. 4 Reconstructing of the early Holocene paleolake in the Nakuru-Elmenteita basin. (a) Transect showing the relationship between the various outcrops shown in Fig. 3 and the highest lake level as reconstructed from paleoshorelines and lake sediments. (b) Correlation of the lake deposits based on sediment characteristics and radiometric age determinations 
extracted from climate datasets obtained from 12 stations within and in the vicinity of the NakuruElmenteita basin (Global Daily Summary 1994; International Station Meteorological Climate Summary 1995; Kenya Meteorological Department 2000) (Table 1). In order to eliminate differences in record length and temporal resolution, we computed annual means and deviations, before we resampled the station data for precipitation and temperature onto a $2500 \mathrm{~m} \times 2500 \mathrm{~m}$ grid. Gridding was performed using a biharmonicspline interpolation with tension (Wessel and Bercovici 1998). From the gridded climate parameters, we then inferred basin-averaged values for precipitation and temperature that are required by the lake-balance model. Climate variables such as cloud cover, relative humidity and windspeed were not gridded prior to averaging since the data coverage in the area is low and the spatial variability of these parameters is believed to be very low. After modeling the hydrological budgets, we tested the sensitivity of the final results for the following parameters: air temperature $\left(T_{\mathrm{a}}\right)$, precipitation rate $(P)$, relative humidity (rh), cloud cover (cc) and windspeed $(U)$ by changing these parameters independently and carefully exploring their influence on the final modeling results.

\section{Results}

The size of the modern catchment is $2390 \mathrm{~km}^{2}$ and the lake surface area is $66 \mathrm{~km}^{2}$. The total volume of the water bodies of lakes Nakuru and Elmenteita is $0.165 \mathrm{~km}^{3}$. For the early Holocene, we utilized the same value for catchment area assuming no change in the geometry caused by tectonic movements and magmatic activity since that time. In contrast, the values for lake surface area and volume of the water bodies decreased significantly since the early Holocene highstand (Table 1). The highest exposures of early Holocene lake sediments were found between 1935

Table 1 Input parameters for the recent and the early Holocene simulation

\begin{tabular}{|c|c|c|c|c|}
\hline Parameter & Units & Modern value & Paleo value & Reference \\
\hline Catchment area & $\mathrm{km}^{2}$ & 2390 & 2390 & $\mathrm{a}, \mathrm{i}, \mathrm{j}$ \\
\hline Lake area $($ Nak+Elm $)$ & $\mathrm{km}^{2}$ & 66 & 760 & $\mathrm{a}, \mathrm{i}, \mathrm{j}$ \\
\hline Max lake level (Nak/Elm) & $\mathrm{m}$ & $1694 / 1780$ & $1940 / 1940$ & $\mathrm{i}$ \\
\hline Lake-area ratio & - & 0.028 & 0.317 & $\mathrm{a}, \mathrm{j}$ \\
\hline Volume of lake water body & $\mathrm{km}^{3}$ & 0.165 & 70.7 & $\mathrm{a}$ \\
\hline Surface temperature & ${ }^{\circ} \mathrm{C}$ & 19.1 & 16.3 & $\mathrm{~b}$ \\
\hline Air temperature & ${ }^{\circ} \mathrm{C}$ & 15.85 & 15.35 & $\mathrm{~b}, \mathrm{~d}$ \\
\hline Surface-drag coefficient $C_{\mathrm{D}}$ & - & 0.004 & 0.0043 & $\mathrm{~d}, \mathrm{f}$ \\
\hline Windspeed & $\mathrm{m} \mathrm{s}^{-1}$ & 2.4 & 2.6 & $\mathrm{~b}$ \\
\hline Cloud fraction & - & 0.57 & 0.62 & $\mathrm{~b}, \mathrm{c}$ \\
\hline Air pressure & $\mathrm{Pa}$ & 81350 & 81350 & $\mathrm{~b}$ \\
\hline Relative humidity & - & 0.65 & 0.70 & $\mathrm{~b}, \mathrm{c}, \mathrm{e}$ \\
\hline \multicolumn{5}{|l|}{ Surface albedo over } \\
\hline Land & - & 0.15 & 0.10 & h, 1 \\
\hline Water & - & 0.085 & 0.85 & h, 1 \\
\hline \multicolumn{5}{|l|}{ Surface emissivity over } \\
\hline Land & - & 0.9 & 0.95 & 1 \\
\hline Water & - & 1.0 & 1.0 & 1 \\
\hline \multicolumn{5}{|l|}{ Soil moisture over } \\
\hline Land & - & 0.37 & 0.70 & h, 1 \\
\hline Water & - & 1.0 & 1.0 & h, 1 \\
\hline Shortwave cloud parameters & - & $0.39,0.38$ & $0.39,0.38$ & $\mathrm{~h}$ \\
\hline Longwave cloud parameters & - & $0.22,2.0$ & $0.22,2.0$ & $\mathrm{~h}$ \\
\hline Cloudfree shortwave radiation & $\mathrm{W} \mathrm{m} \mathrm{m}^{-2}$ & 415 & 415 & $\mathrm{k}$ \\
\hline
\end{tabular}

(a) values taken from the digital elevation model; (b) GDS (1994), ISMCS (1995), KMD (2000); (c) Griffith (1972); (d) Jätzold (1981); (e) Vincent et al. (1979); (f) Hecklau (1989); (g) Rohde and Virji (1976); (h) Bourgeault (1991); (i) Washbourn (1967a); (j) Hastenrath and Kutzbach (1983); (k) Berger and Loutre (1991); (l) surface pattern-related parameters as attributed to vegetation mapping 
and $1940 \mathrm{~m}$, which is in line with the observations by Washbourn (1967b) (Fig. 4). Corresponding paleoshorelines were mapped at Karterit volcano in the southern part of the basin (K1). At this site, three parallel shorelines can be observed at the tuff cone (Fig. 5). In the northern part of the Nakuru-Elmenteita basin, Washbourn-Kamau (1970; 1971) described a series of paleoshorelines on the southern rim of Menengai at similar altitudes. Unfortunately, these shorelines are not preserved due to the expansion of the city of Nakuru. Higher shorelines, in particular at the elevation of the corresponding shorelines in the Naivasha basin $(2000 \mathrm{~m})$ are not yet identified in the Elmenteita-Nakuru basin. However, it cannot be excluded that higher shorelines were eroded since the early Holocene. The age of the paleoshorelines was confirmed by ${ }^{14} \mathrm{C}$ ages of snail shells sampled from the associated lake sediments (Fig. 4). The ages for these fossils range from 9,333 cal. yr BP (Lemulug outcrop, K2) to 12,579 cal. yr BP (outcrop east of Lake Elmenteita, K3) (Table 2). These ages are in good agreement with an age ranging between 10,258 and 11,806 cal. yr BP at Karterit volcano (K1) (Washbourn-Kamau 1970). Based on the elevation of paleoshorelines and associated lake deposits, the paleolake area during the early Holocene highstand was $757 \pm 3 \mathrm{~km}^{3}$. Thus, the early Holocene lake area was $12 \times$ larger than the lake surface today (Fig. 3). The corresponding volume of the paleowaterbody is $70 \pm 0.7 \mathrm{~km}^{3}$.

The modern basin-averaged precipitation rate $\left(P_{\text {bas }}\right)$ was inferred from data of 12 meteorological stations and maps of precipitation distribution in the Central Kenya Rift. We computed a basinaveraged value of $920 \mathrm{~mm} \mathrm{yr}^{-1}$ from gridded precipitation values (Table 3). Applying the same procedure for air temperature $\left(T_{\mathrm{a}}\right)$, we calculated a mean annual value of $15.9^{\circ} \mathrm{C}$ (Table 1$)$. The mean annual surface temperature $\left(T_{\mathrm{s}}\right)$ was obtained by calculating basin-averaged evaporation resulting in a value of $19.1^{\circ} \mathrm{C}$. The averaged cloud cover (cc) of $57 \%$ was obtained from four stations at Nakuru, Naivasha, Equator and Nyahuru (Griffith 1972; GDS 1994; ISCMS 1995; Kenya Meteorological Department 2000). The basinaveraged relative humidity (rh) of $65 \%$ was determined from seven climate stations (Griffith 1972; Vincent et al. 1979; GDS 1994; ISCMS 1995). Windspeed $(U)$ based on the data from four climatic records has a basin-mean of

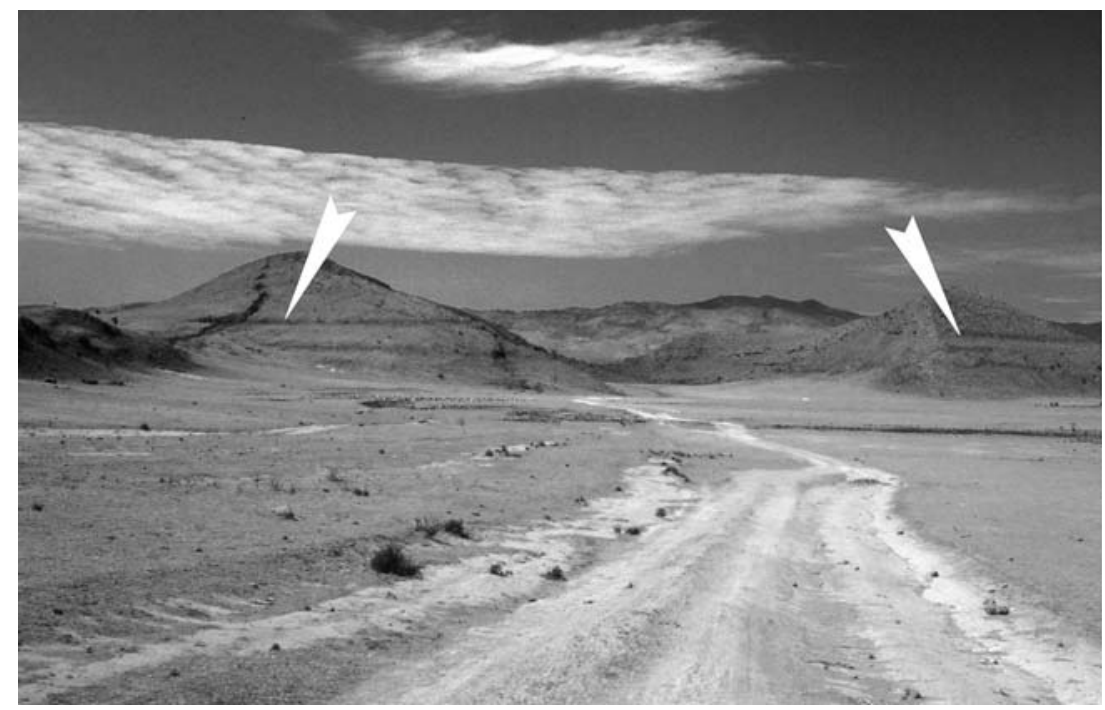

Fig. 5 Three parallel shorelines exposed on the flanks of Katerit volcano (view from the north). The highest paleoshoreline (indicated by arrows) is at $\sim 1940 \mathrm{~m}$ above sea level, whereas the lowest shorelines is at $1880 \mathrm{~m}$. Radiocarbon-dated lake sediments associated with the highest shoreline suggest that it formed during the early Holocene maximum lake level highstand (Richardson and Dussinger 1986). The normal fault shown in the left part of the photograph displaces the highest shoreline by $\sim 2.5 \mathrm{~m}$ 
Table 2 Radiocarbon analysis at Lake Elmenteita

\begin{tabular}{llcc}
\hline Lab number & Sample location & $1 \sigma$ AMS date $\left({ }^{14} \mathrm{C}\right.$ yr BP $)$ & $2 \sigma$ calibrated age range (cal. yr BP) \\
\hline KIA $13108^{\mathrm{a}}$ & Lemulug outcrop & $10,390 \pm 45$ & $12,073-12,579$ \\
KIA $13109^{\mathrm{a}}$ & Elmenteita outcrop & $8,440 \pm 40$ & $9,333-9,531$ \\
${ }_{-}^{\mathrm{b}}$ & Karterit volcano & $9,650 \pm 250$ & $10,258-11,806$ \\
\hline
\end{tabular}

Note: Calendar year ages were determined with CALIB 5.0.1 (Stuiver and Reimer 1993)

a Sample number assigned at radiocarbon laboratory (Leibniz laboratory Kiel, Germany)

b No lab number available; AMS age for the locality Karterit volcano was taken from Washbourn-Kamau (1970)

Table 3 Hydrological model outputs for the modern and the early Holocene simulation

\begin{tabular}{llrl}
\hline Parameter & Units & Modern value $^{\mathrm{a}}$ & Paleo value $^{\mathrm{b}}$ \\
\hline Basin averaged evaporation rate over & & 870 & 1170 \\
$\quad$ Land & $\mathrm{mm} \mathrm{yr}^{-1} \mathrm{~m}^{-2}$ & 1830 & 1850 \\
$\quad$ Water & $\mathrm{mm} \mathrm{yr}^{-1} \mathrm{~m}^{-2}$ & 920 & 1330 \\
Basin averaged precipitation rate & $\mathrm{mm} \mathrm{yr}^{-1} \mathrm{~m}^{-2}$ & \\
\hline
\end{tabular}

a The modern run uses the data from GDS (1994) as cross-check for the modeling results

b The paleovalues are the best scenario for evaporation and precipitation in the basin during the early Holocene

$2.4 \mathrm{~m} \mathrm{~s}^{-1}$ (GDS 1994; ISCMS 1995; Kenya Meteorological Department 2000). The value for air pressure of $813.5 \mathrm{hPa}$ was determined from data by GDS (1994), ISCMS (1995) and the Kenya Meteorological Department (2000). The surface drag coefficient $C_{\mathrm{D}}$ characterizes height and type of vegetation, which is an important empirical parameter in the estimation of evaporation (Bougeault 1991).

$C_{\mathrm{D}}=\kappa^{2} \ln \left(\frac{z_{\mathrm{r}}}{z_{0}}\right)^{-2}$

where $\kappa$ is the Karman constant, $z_{\mathrm{r}}$ denotes the reference height at which the windspeed is measured and $z_{0}$ is the roughness height where the windspeed is zero (Rowntree 1991). The modern vegetation coverage in the Nakuru-Elmenteita catchment was obtained from vegetation maps (Survey of Kenya 1974; Jätzold 1981; Hecklau 1989) and own field observations. The inferred vegetation pattern includes $56 \%$ pastures and farming land, $36 \%$ savanna grassland and $8 \%$ of forest and water surfaces. Taking this vegetation distribution into account, we computed a $C_{\mathrm{D}}$ of 0.004. Furthermore, we assumed an emissivity of 0.9 for land and 1.0 for water, albedo of 0.15 for land and 0.085 for water and soil moisture of 0.37 for land and 1.0 for water (Table 1) (Bougeault 1991). Short- and long-wave cloud parameters as well as cloud-free shortwave radiation were taken from Shuttleworth (1991) and Griffith (1972). Because of the scarcity of some climate records, the calculated values have to be considered carefully, especially in cases of temperature, cloud coverage, relative humidity and windspeed. For this reason, the sensitivity tests provide important information on the model-parameter relationship.

For most of the climate parameters we do not have good values for the early Holocene. However, a suite of estimates and assumptions exist from previous works (Hastenrath and Kutzbach 1983; Maitima 1991; Street-Perrott and Perrott 1993; Bergner et al. 2003). Considering a stronger intertropical convergence during the early Holocene due to higher insolation values, an increase in relative humidity ( $\mathrm{rh}$ ), cloud cover (cc) and windspeed $(U)$ seemed to be realistic (Table 1$)$. We preferred a relatively moderate change of these parameters compared to the modern conditions and assumed a 5-10\% higher value for each of them. We also reconstructed the early Holocene vegetation in the area. Pollen data for that time suggest a higher ratio between forested areas and savanna grassland as compared to the modern conditions (Maitima 1991; Street-Perrott 
and Perrott 1993). A reasonable scenario for the early Holocene is a $30 \%$ fraction of open waters, $25 \%$ of forest and $45 \%$ of savanna grassland. The pollen data also suggest a lower mean-annual temperature for that time due to increased cloudiness (Street-Perrottt and Perrott 1993). Since temperature strongly influences evaporation and hence the hydrological budget of the basin, we introduced a relatively conservative value of $0.5^{\circ} \mathrm{C}$ temperature reduction to our model. From the adapted vegetation coverage we derived an early Holocene value for the surface drag coefficient $C_{\mathrm{D}}=0.0043$, an $8 \%$ increase to the modern value. Albedo, emissivity and soil moisture are in close relationship with vegetation cover and therefore their values also changed from modern to the early Holocene scenario. While the value for albedo decreases with increasing vegetation cover, the values for emissivity and soil moisture increase with a higher vegetation cover (Benjamin and Carlson 1986). Regarding these values as accurate, the early Holocene model run yielded a minimum increase in basin-averaged precipitation of $45 \%$ (Table 3 ).

Next, we tested the robustness of our modeling results by means of various sensitivity tests. This testing was done for the following parameters: air temperature $\left(T_{\mathrm{a}}\right)$, precipitation $(P)$, relative humidity (rh), cloud coverage (cc) and windspeed $(U)$. In a first run, we investigated the sensitivity of the evaporation rate for the recent and the paleosituation with a $10 \%$ increase of each parameter (Table 4). The result for the recent condition shows that a variation in precipitation

Table 4 Sensitivity tests for the recent and the early Holocene simulation

\begin{tabular}{lll}
\hline Parameter & $\Delta E$ in $\%$ & \\
\cline { 2 - 3 } & Modern & Paleo \\
\hline Precipitation $(P)$ & -1.6 & -1.1 \\
Temperature $(T)$ & +5.2 & +5.2 \\
Windspeed $(U)$ & +3.3 & +3.2 \\
Cloud fraction $(\mathrm{cc})$ & -5.5 & -6.3 \\
Relative humidity $(\mathrm{rh})$ & -3.2 & -4.5 \\
\hline
\end{tabular}

Results for the sensitivity tests, representing evaporation variabilities $(\Delta E)$, calculated by an increase of $10 \%$ for each of the listed parameters. In both scenarios, changes of temperature and cloud fraction have the most influence on the evaporation calculations rate $(P)$ has to be balanced by a change in evaporation by only $-1.6 \%$ and therefore exerts only minor importance on the final result. Even though the other parameters temperature $\left(T_{\mathrm{a}}\right)$, relative humidity (rh), windspeed $(U)$, and cloud cover (cc) exhibit a stronger response with an evaporation increase and decrease, respectively, between -3.2 and $+5.2 \%$, their influence on the modeling is limited. For the early Holocene lake highstand, the sensitivity tests exhibit a slightly stronger influence of relative humidity ( $\mathrm{rh}$ ) and cloud coverage (cc) on the modeling results with an evaporation decrease of -4.5 and $-6.3 \%$. Precipitation $(P)$ and windspeed $(U)$ change evaporation by -1.1 and $+3.2 \%$ and thus exert a lower influence compared to recent conditions, whereas air temperature $\left(T_{\mathrm{a}}\right)$ has a similar importance with an evaporation increase of $+5.2 \%$. Consequently, significant changes in the hydrological budget are most likely caused by changes in cloud cover and temperature. By using the sensitivity of one parameter, we can estimate how the deviation of the climatic input data is compensated. Generally, a dataset with high standard deviation will influence the model results much more if its sensitivity is also high.

As a second run, we compared modeled parameters with given values from the meteorological datasets. For recent evaporation over water, the model calculated a value of $1834 \mathrm{~mm} \mathrm{yr}^{-1} \mathrm{~m}^{-2}$. In comparison, the given values for two meteorological stations in Nakuru and Naivasha range between 1736 and $1857 \mathrm{~mm} \mathrm{yr}^{-1} \mathrm{~m}^{-2}$. This shows that the computed evaporation value is reliable and does not significantly differ from the measured value.

In conclusion, the sensitivity tests give reasonable values, which allow us to use the hydrological modeling as a tool for estimating the recent and paleoconditions in the Nakuru-Elmenteita basin. Therefore, we can regard a minimum precipitation increase of about $45 \%$ in the Nakuru-Elmenteita basin as the best estimate for the reconstructed paleoconditions.

\section{Discussion and conclusion}

The Nakuru-Elmenteita basin did not experience major volcano-tectonic movements since the 
early Holocene (Blisniuk 1988; Strecker et al. 1990). Therefore, we assume that the morphology of the catchment, the configuration of the drainage network and the location of shorelines and lake sediments were not significantly different from today. Minor tectonic displacements that affected some areas in the southeastern corner of the basin are in the order of 1-3 m (Blisniuk 1988). As an example, a west-dipping normal fault on the flanks of Katerit volcano displaced the highest shoreline by $2.5 \mathrm{~m}$ (Fig. 5). This fault is part of an en-enchelon suite of north-south trending faults in the active inner part of the rift (Blisniuk 1988; Clarke et al. 1990). Such vertical movements, however, are of the same order of magnitude as the uncertainties of our GPS and altimeter readings. We therefore neglect volcanotectonic movements in our basin reconstruction for the early Holocene.

Today, the Nakuru-Elmenteita basin has no surface outlet. No reliable data are available for subsurface groundwater flow in and out of the basin. Although the thick pile of clayey sediment in the deeper parts of the basin might prevent significant seepage, the faulted marginal parts of the basins are probably excellent pathways for groundwater. However, the known quantities of groundwater movements are of minor importance compared to the annual and inter-annual fluctuations in precipitation and evaporation. In contrast, significant surface water flows in and out of the basin have often been proposed (Nilsson 1931; Washbourn-Kamau 1971; Richardson and Dussinger 1986). For instance, a surface overflow of the early Holocene lake into the Menengai caldera, as often discussed in the literature (Washbourn-Kamau 1971; Richardson and Dussinger 1986), would underestimate the precipitation-evaporation ratio in a closed-basin simulation (Fig. 3). The barrier between the Nakuru-Elmenteita basin and the Menengai caldera is at about $1950 \mathrm{~m}$, which is $10 \mathrm{~m}$ above the highest known level of the early Holocene lake. Even though an overflow cannot be ruled out completely, no sediments that could be attributed to a major overflow event into the Menengai caldera were found at this location in the northern Nakuru-Elmenteita basin.
Widely distributed paleoshorelines at $1940 \mathrm{~m}$ suggest a hydrologically stable period. We therefore use this altitude to reconstruct the early Holocene lake and calculate the precipitationevaporation ratio that might have caused this lake to form. Accepting an outlet in the northern part of the basin, our estimate is a minimum value for the true hydrological budget. Our hydrological modeling reveals an early Holocene precipitation increase of about $45 \%$ compared to today. Washbourn (1967a) and Butzer et al. (1972) modeled an early Holocene precipitation increase of $65 \%$. In contrast, Hastenrath and Kutzbach (1983) estimated an increase of $30-35 \%$ for the Nakuru-Elmenteita basin. It is interesting to note that precipitation values calculated for other East African basins are generally lower than the value modeled for Nakuru-Elmenteita. For instance, Beuning and Russell (2004) suggest a 25-60\% precipitation increase based on palynological data from the Lake Edward basin. Bergner et al. (2003) recently applied our hydrological model to the Naivasha basin and found a $16-32 \%$ increase in rainfall compared to present, depending on the contribution of a vegetation change in the course of climate change. Hastenrath and Kutzbach (1983) modeled a precipitation increase of 10-20\% for the Naivasha, Turkana and Victoria basins. All authors emphasize that their results were significantly influenced by the values for land albedo and the Bowen ratio, which certainly is a weak point of lake-balance models in general.

One reason for the discrepancy between different modeling results might be attributed to the quality of the applied model and/or the input parameters. The modeling results of Washbourn (1967a) and Butzer et al. (1972) are the highest out of all values. They used a simplified hydrological model neglecting changes in vegetation coverage, temperature or relative humidity. Since these environmental parameters have important influence on the evaporation rate of the catchment, higher precipitation values are necessary to compensate for the humidity deficit. The approach of Hastenrath and Kutzbach (1983) reveals differences in the modeling results, but the ratio of calculated precipitation increase for the Nakuru-Elmenteita basin and the Naivasha 
basin is similar compared to our result and results of Bergner et al. (2003).

In any case, the modeling suggests that the early Holocene precipitation rate for the Nakuru-Elmenteita basin is about $\sim 20$ to $25 \%$ higher than the rate for the Naivasha basin. This striking difference in the hydrological budget might be attributed to true differences in local climate. However, due to the spatial proximity of these two catchments and the similarities in the physiogeographic situation we do not expect major climatic differences in these two basins. Instead, we suggest an occasional linkage between the Naivasha and the Nakuru-Elmenteita basin with a water flow from the south to the north (Fig. 2). A significant overflow at the Gilgil Escarpment in the southestern corner of the Nakuru-Elmenteita basin has already been proposed by Thompson and Dodson (1963), whereas Nilsson (1931) even postulated a single large Gamblian lake for both basins. We explored the site of a potential overflow but did not find any evidence for a connection between the two early Holocene lakes. The topographically lowest point between the Nakuru-Elmenteita and the Naivasha basin is at $2010 \mathrm{~m}$ above sea level, i.e. $10 \mathrm{~m}$ above the highest maximum lake level of Lake Naivasha. Therefore, it is unlikely that both paleolakes were connected to one single lake during the early Holocene. A significant groundwater flow, however, from the Naivasha into the Nakuru-Elmenteita basin cannot be excluded. The hydraulic gradient between the lakes at $2000 \mathrm{~m}$ (Naivasha) and 1940 m (Nakuru-Elmenteita), respectively, certainly caused such a northward waterflow and balanced the hydrological deficit of the NakuruElmenteita basin.

Accepting a significant groundwater flow out of the Naivasha into the Nakuru-Elmenteita basin would then reduce the modeled precipitationevaporation balance for the northern basin, whereas this quantity would slightly increase the value for the southern basin. An exact determination of this groundwater exchange, however, requires a much better knowledge of the permeability of the barrier between the two basins and the contribution of groundwater movements from the surrounding regions. The basin margins should be mapped in detail to prove or disprove the existence of potential surface overflows. Finally, a coupled hydrological model for both lake basins allows a better estimate of the true regional climate conditions during the early Holocene. Such an improved model requires a solid knowledge of the modern hydrological conditions as well as the exact feedbacks in the climate-hydrology causal linkage such as vegetation changes and their influences on evaporation is also required.

Our results show the difficulties in reconstructing and modeling paleolakes in the Central Kenya Rift. Nevertheless, the comparison of modeling results from two adjacent basins now provides some contraints for hydrological changes in the area and a better estimate for the precipitation-evaporation ratio during the early Holocene. The modeled values of $10-30 \%$ more precipitation are of the same order of magnitude as the results from other East African basins and provide valuable insights into the natural climate variability during the Holocene.

Acknowledgements This project was funded by the German Research Foundation (DFG). We thank the government of Kenya and the Kenya Wildlife Service for research permits and support. We gratefully acknowledge B. Bookhagen for his support with the hydrological model and comments on the manuscript. We are also thankful to M.R. Strecker who provided advice and support during this project. We thank P. Blisniuk, S. Gaciri, F. Gasse, G. Muchemi, C. Nyamweru and D. Verschuren for discussions. T. Schlueter and M. Ibs-von Seht are acknowledged for their logistical support. We thank the journal editor as well as J.C. Stager and an anonymous reviewer for their helpful comments on the manuscript.

\section{References}

Barker PA, Williamson D, Gasse F, Gibert E (2003) Climatic and volcanic forcing revealed in a 50,000-year diatom record from Lake Massoko, Tanzania. Quaternary Res 60:368-376

Beadle LC (1932) Observations on the bionomics of some East African swamps. J Linn Soc (Zool) 28:135-155

Benjamin SG, Carlson TN (1986) Some effects of surface heating and topography on the regional severe storm environment-Part 3: three dimensional simulations. Mon Weather Rev 114:330-343

Berger A, Loutre MF (1991) Insolation values for the climate of the last 10 million years. Quaternary Sci Rev 10:297-317

Bergner AGN, Trauth MH, Bookhagen B (2003) Paleoprecipitation estimates for the Lake Naivasha Basin (Kenya) during the last 175 k.r. using a lake-balance model. Global Planet Change 36:117-136 
Beuning KRM, Russell JM (2004) Vegetation and sedimentation in the Lake Edward Basin, Uganda-Congo during the late Pleistocene and early Holocene. J Paleolimnol 32:1-18

Blisniuk PM (1988) Geologie des Lake Elmenteita Gebietes, Zentrales Kenya Rift. Diploma Thesis, Universität Karlsruhe, Germany

Blodgett TA, Lenters JD, Isacks BL (1997) Constraints on the origin of paleolake expansion in the central Andes available online at (http://www.earthinteractions.org)

Bookhagen B, Haselton K, Trauth MH (2001) Hydrological modeling of a Pleistocene landslide-dammed lake in the Santa Maria Basin, NW Argentina. Palaeogeogr Palaeoclimatol Palaeoecol 169:113-127

Bougeault P (1991) Evaporation models in hydrology. In: Schmugge TJ, André JC (eds) Land surface evaporation-measurement and parameterisation. Springer, New York, pp 93-120

Butzer KW, Isaac GL, Richardson JL, Washbourn-Kamau C (1972) Radiocarbon dating of East African lake levels. Science 175:1069-1076

Clarke MCG, Woodhall DG, Allen D, Darling G (1990) Geological, volcanological and hydrogeological controls on the occurrence of geothermal activity in the area surrounding Lake Naivasha, Kenya. British Geological Survey Report and Government of Kenya-Ministry of Energy, Nairobi, Kenya

Gasse F (2000) Hydrological changes in the African tropics since the last glacial maximum. Quaternary Sci Rev 19:189-211

Gasse F, van Campo E (1994) Abrupt post-glacial climate events in West Asia and North Africa monsoon domains. Earth Planet Sci Lett 126:435-456

Global Daily Summary, GDS-Temperature and precipitation, CD-Rom Vers. 1.0 (1994) Federal climate complex Asheville, national oceanic and atmospheric administration, Department of Commerce, Washington, USA

Griffith JF (1972) Climates of Africa. In: World survey of climatology, vol 10. Elsevier Publishing Company, Amsterdam, Netherlands

Hastenrath S, Kutzbach JE (1983) Paleoclimatic estimates from water and energy budgets of East African lakes. Quaternary Res 19:141-153

Hecklau H (1989) Ostafrika-Kenya, Tanzania, Uganda. In: Wissenschaftliche Länderkunden, vol 33. Wissenschaftliche Buchgesellschaft, Darmstadt, Germany

International Station Meteorological Climate Summary, ISMCS, CD-Rom Vers. 3.0 (1995) Federal climate complex Asheville, National Oceanic and Atmospheric Administration, Department of Commerce, Washington, USA

Jätzold R (1981) Klimageographie-Ostafrika, Kenya, Uganda, Tanzania $2^{\circ} \mathrm{N}-2^{\circ} \mathrm{S}, 32^{\circ}-38^{\circ} \mathrm{E}$. In: Freitag U (ed) Afrika-Kartenwerk, Serie E, Beiheft zu Blatt 5. Bornträger Stuttgart, Germany

Kenya Meteorological Department (2000) Unpublished synoptic and rain station data. Ministry of Information, Transport and Communications, Nairobi, Kenya

Kutzbach JE (1980) Estimates of past climate at paleolake Chad, North Africa, based on a hydrological and energy-balance model. Quaternary Res 14:210-223
Kutzbach JE, Street-Perrott FA (1985) Milankovitch forcing of fluctuations in the level of tropical lakes from 18 to 0 kyr BP. Nature 317:130-134

Maitima JM (1991) Vegetation response to climatic change in Central Rift Valley, Kenya. Quaternary Res 35:234-245

Nicholson SE (1996) A review of climate dynamics and climate variability in Eastern Africa. In: Johnson TC, Odada E (eds) The limnology, climatology and paleoclimatology of the East African lakes-The international decade for the East African lakes, IDEAL. Gordon and Breach Publishers, Amsterdam, pp 25-56

Nicholson SE (2000) The nature of rainfall variability over Africa on time scales of decades to millennia. Global Planet Change 26:137-158

Nilsson E (1931) Traces of ancient change of climate in East Africa. Geogr Ann 17:1-21

Richardson JL, Dussinger RA (1986) Paleolimnology of mid-elevation lakes in the Kenya Rift Valley. Hydrobiologia 143:167-174

Richardson JL, Richardson AE (1972) History of an African Rift lake and its climatic implications. Ecolo Monogr 42:499-535

Rohde H, Virji H (1976) Trends and periodicities in East African rainfall data. Mon Weather Rev 104:307-315

Rowntree PR (1991) Atmospheric parameterization schemes for evaporation over land: basin concepts and climate modelling aspects. In: Schmugge TJ, André JC (eds) Land surface evaporation-measurement and parameterisation. Springer, New York, pp 5-29

Shuttleworth WJ (1991) Parameterization schemes of land-surface processes for mesoscale atmospheric models. In: Schmugge TJ, André JC (eds) Land surface evaporation-measurement and parameterisation. Springer, New York, pp 55-92

Strecker MR (1991) Das zentrale und südliche Kenya-Rift unter besonderer Berücksichtigung der neotektonischen Entwicklung. Habilitation thesis, Universität Karlsruhe, Germany

Strecker MR, Bosworth W (1991) Quaternary stress-field change in the Gregory Rift, Kenya. Eos, Transactions, Am Geophys Union 72:17-22

Strecker MR, Blisniuk P, Eisbacher G (1990) Rotation of extension direction in the central Kenya Rift. Geology 18:299-302

Street-Perrott FA, Perrott RA (1993) Holocene vegetation, lake levels and climate of Africa. In: Wright HE Jr, Kutzbach JE, Webb T, Ruddimann WF, StreetPerrott FA, Bartlein, PJ (eds) Global climates since the last glacial maximum. University of Minnesota Press, Mineapolis, pp 318-356

Stuiver M, Reimer PJ (1993) Extended ${ }^{14} \mathrm{C}$ database and revised CALIB radiocarbon calibration program. Radiocarbon 35:215-230

Survey of Kenya (1974) Topographic map East Africa 1.50.000, Kenya. Kenya Government, Nairobi, Kenya

Talling JF, Talling IB (1965) The chemical composition of African lake waters. Int Rev Ges Hydrobiol 50:421-463 
Thompson AD, Dodson R (1963) Geology of the Naivasha Area. Geological Survey of Kenya, Nairobi, Kenya. Report 55

Thompson LG, Mosley-Thompson E, Davis ME, Henderson KA, Brecher HH, Zagorodnov VS, Mashiotta TA, Lin, PN, Mikhalenko VN, Hardy DR, Beer J (2002) Kilimanjaro ice core records: evidence of Holocene climate change in tropical Africa. Science 298:589-593

Trauth MH, Deino AL, Bergner AGN (2003) East African climate change and orbital forcing during the last $175 \mathrm{kyr}$ BP. Earth and Planetary Science Letters 206:297-313

Vincent CE, Davies TD, Beresford AKC (1979) Recent changes in the level of Lake Naivasha, Kenya, as an indicator of Equatorial Westerlies over East Africa. Climatic Change 2:175-189
Washbourn C (1967a) Late quaternary lakes in the Nakuru-Elmenteita Basin, Kenya. PhD Thesis, University of Cambridge, UK

Washbourn C (1967b) Lake levels and Quaternary climates in the eastern Rift Valley of Kenya. Nature 216:672-673

Washbourn-Kamau C (1970) Late Quaternary chronology of the Nakuru-Elmenteita Basin, Kenya. Nature 226:253-254

Washbourn-Kamau C (1971) Late Quaternary lakes in the Nakuru-Elmenteita Basin, Kenya. Geograph J 137:522-535

Wessel P, Bercovici D (1998) Interpolation with splines in tension: a Greens function approach. Math Geol 30:77-93 